\title{
FENOMENOLOGI SEBAGAI METODE PENGEMBANGAN EMPATI DALAM ARSITEKTUR
}

\author{
Angelyna $^{1)}$, Franky Liauw ${ }^{21}$ \\ 1)Program Studi S1 Arsitektur, Fakultas Teknik, Universitas Tarumanagara, \\ angelyna.hermanto@gmail.com \\ 2)Program Studi S1 Arsitektur, Fakultas Teknik, Universitas Tarumanagara, frankyl@ft.untar.ac.id
}

Masuk: 13-07-2020, revisi: 28-07-2020, diterima untuk diterbitkan: 23-09-2020

\begin{abstract}
Abstrak
Seiring perkembangan zaman, manusia semakin berkembang pula. Perubahan sifat manusia menjadi pemegang kunci utama yang tanpa disadari menimbulkan salah satunya dalam hal sosial. Teknologi, ekonomi, pengetahuan, keamanan, tingkat sosial, dan tempat menjadi faktor yang mempengaruhi perubahan sosial manusia. Perubahan sosial tersebut seperti manusia yang individualis dan tidak peduli terhadap lingkungan sekitar, sehingga kata empati seakan tidak ada saat ini, terutama di daerah perkotaan. Empati termasuk kemampuan untuk merasakan keadaan emosional orang lain, merasa simpatik dan mencoba menyelesaikan masalah, dan mengambil perspektif orang lain (Baron \& Byrne, 2004). Faktanya, studi terbaru menunjukan rasa empati dalam diri seseorang semakin langka, sebanyak 65\% orang bersikap tidak peduli atau kehilangan empati (Daily mail, 2019). Padahal empati merupakan hal penting menurut Graaff dkk, (2014), empatilah yang menggaris bawahi pentingnya kemampuan, tingkah laku dan sebuah peran yang sangat penting dalam pengembangan moral dan perilaku prososial. Menurutnya tingkat empati masyarakat di kota besar menjadi faktor utama bagi perancang untuk merancang sebuah Wadah Pengembangan Empati Pegadungan yang dapat menjaga maupun mengembangkan rasa empati tersebut melalui pendekatan fenomenologi indera manusia, sebagai wadah pelatihan untuk merasakan emosi sesama melalui ruang arsitektur, salah satunya pada labirin. Proyek ini menggunakan metode dari teori Juhani Pallasmaa "An architecture of seven sense" dan "The eyes of the skin: architecture and sense" dan melalui pengumpulan data dari BPS DKI Jakarta, jurnal ilmiah, e-book, survei, wawancara dan kuisioner, serta analisis kebutuhan masyarakat sekitar. Dengan ini diharapkan rasa empati tetap terasa dan terjaga sampai kapanpun, dengan desain sesuai dengan karakteristik empati.
\end{abstract}

Kata kunci: empati; fenomenologi; indera; labirin; Pegadungan

\begin{abstract}
Along with the times, humans gradually growing too. This different time which is the main holder of changes in human nature that unconsciously causing many things, like in social terms. Technology, economy, knowledge, safety, social level, and place become a factor that affect human's social changes. These social changes can refer to individualistic and do not care about the surrounding environment, so empathy seems to never be heard agin in this era, especially in urban. Empathy includes the ability to feel the emotional statre of others, feel sympathetic and try to slove problems, and take other people's perspective (Baron \& Byrne, 2004),. While the fact from recent studies have shown that empathy in a person is becoming increasingly rare, as many as 65 percent of people do not care or lose empathy (Daily Mail, 2019). Though empathy itself is important according to Graaff et al (2014) where empathy which underlines the importance of ability, behavior and a very important role in the development of moral and prosocial. The reduced level of empathy in urban is a major factor for designers to design a Pegadungan Empathy Development a place that can maintain and develop empathy through the phemomenology approach using human senses, as a training to feel the emotions of others through architectural space, one of them by labyrinth. The method project from Juhani Pallasmaa theories "An
\end{abstract}


Architecture of Seven Sense" and "The Eyes of The Skin: Architecture and Sense" and through data collection from DKI Jakarta BPS, scientific journals, e-books, survey, interview and questionnaires, and local society needs analysis. With this, this project expected that empathy can be felt and maintained at any time, with a design in accordance with the characteristic of empathy.

Keywords: empathy; labyrinth; Pegadungan; phenomenology; sense

\section{PENDAHULUAN}

\section{Latar Belakang}

Pada dasarnya, manusia adalah makhluk sosial yang tidak dapat hidup sendiri dan akan selalu berdampingan serta membutuhkan sesama. Selain dari kebutuhan primer, sekunder, dan tersier, kebutuhan akan bersosialisasipun tak kalah pentingnya bagi kehidupan manusia. Salah satunya empati yang merupakan sebuah kegiatan bersosial yang melibatkan dua orang atau lebih. Namun seiring perkembangan zaman, teknologi, dan pengetahuan yang berkembang pesat terutama di daerah perkotaan perlahan akan mempengaruhi sifat manusia itu sendiri.

Perkembangan zaman memang sangat dibutuhkan untuk mencapai sebuah kehidupan yang nyaman dan berguna bagi manusia, namun tentu saja setiap hal memiliki dampak positif maupun negatif. Beberapa hal ini dipengaruhi oleh status sosial, pekerjaan, keamanan, pengetahuan, bahkan tempat di mana masyarakat berada turut ikut serta dalam menjadikan manusia menjadi individualis dan tidak peduli terhadap sekitar. Sedangkan faktanya, studi terbaru menunjukan rasa empati dalam diri seseorang semakin langka, yaitu sebanyak 65 persen orang bersikap tidak peduli atau kehilangan empati (Daily mail, 2019). Empati juga dapat dilihat dari pola interaksi di desa maupun kota, di mana masyarakat kota cenderung tidak terbiasa bergantung pada orang lain sehingga memiliki sifat individualitas. Sedangkan di desa masih menekankan pada unsur saling bergantung dan menjunjung tinggi kebersamaan. Padahal empati sendiri merupakan hal penting menurut Graaff dkk (2014), di mana empatilah yang menggarisbawahi pentingnya kemampuan, tingkah laku dan sebuah peran yang sangat penting dalam pengembangan moral dan perilaku prososial.

Maka dari itu, empati satu sama lain sangat diperlukan untuk membangun relasi sosial dan rasa peduli. Empati sendiri berasal dari bahasa Yunani $\varepsilon \mu \pi \alpha \dot{\vartheta} \varepsilon \iota \alpha$ yang berarti "ketertarikan fisik" yang diartikan sebagai respons afektif dan kognitif yang kompleks pada distres emosional orang lain. Empati termasuk kemampuan untuk merasakan keadaan emosional orang lain, merasa simpatik dan mencoba menyelesaikan masalah, dan mengambil perspektif orang lain (Baron \& Byrne, 2004). Maka untuk mewujudkan hal tersebut, dibutuhkan sebuah wadah pengembangan empati untuk daerah perkotaan agar masyarakat perkotaan dapat merasakan kembali dan terus mengembangkan empati.

\section{Rumusan Permasalahan}

Berdasarkan latar belakang di atas diketahui terdapat masalah yang terjadi, yaitu:

a. Terdapat isu tingkat empati di kota besar yang sangat rendah dan menurun

b. Pentingnya sikap empati dalam kehidupan sosial

c. Dampak penurunan empati yang menyebabkan masalah sosial serta masyarakat yang individualis dan tidak peduli terhadap sekitar 


\section{Tujuan}

a. Masyarakat dapat merasakan apa yang dirasakan orang lain sebagai tahap awal dalam proses pengembangan empati dengan melatih perasaan dan perspektif terhadap diri sendiri

b. Peduli dan membantu sesama, proses setelah masyarakat keluar dari masalah menimbulkan sikap prihatin dan peduli kepada orang lain berdasarkan pengalaman pribadi, sehingga memungkinkan untuk membantu sesama

c. Bersenang-senang bersama setelah membantu orang lain sambil melupakan masalah yang telah dialami dengan memulai sesuatu yang baru dan menyenangkan

d. Proses dari awal hingga akhir akan menumbuhkan rasa empati secara tidak langsung bagi masyarakat melalui pengalaman yang dirasakan

e. Belajar dan menyalurkan cerita mengenai empati melalui program yang telah disediakan

f. Memberikan fasilitas bersama untuk mewadahi aktifitas masyarakat sekitar.

\section{KAJIAN LITERATUR}

\section{Empati}

Empati merupakan sebuah kemampuan untuk memahami perasaan dan masalah orang lain, berpikir dengan sudut pandang mereka, serta menghargai perbedaan perasaan orang lain tentang berbagai hal (Daniel Goleman, 1996). Selain itu, beliau mengutip dari Martin Hoffman (2000), bahwa sumber utama dari moralitas berada pada empati karena dalam keadaan susah dengan seseorang, kita merasa tergerak untuk membantu.

\section{Hubungan Empati dengan Indrea dan Emosi}

Indera manusia sangat berkaitan dengan empati yang menjadi sebuah dasar untuk membangun hubungan sosial dengan orang lain (Daniel Goleman, 1996). Self awareness akan terfokus pada pengalaman emosi dan dalam empati akan teralih pada emosi orang lain. Maka dari itu, jika seseorang dapat mengetahui emosi dirinya sendiri, maka semakin terampil pula untuk dapat membaca emosi orang lain. Sehingga dapat disimpulkan empati sebagai kemampuan mengindera perasaan dari sudut pandang orang lain.

\section{Ciri-ciri Kemampuan Empati}

Terdapat 3 ciri-ciri kemampuan empati yang dapat disebut sebagai bagian dari kecerdasan emosional (Daniel Goleman, 1996), yaitu:

a. Empati kognitif, mendengarkan orang lain dengan baik; seseorang harus dapat fokus mendengarkan dan memberi perhatian terhadap permasalahan orang lain

b. Empati afektif, menerima sudut pandang orang lain; seseorang dapat melihat permasalahan dari sudut pandang orang lain sehingga mampu menerima perbedaan

c. Empati belas kasih, peka terhadap perasaan orang lain; seseorang dapat membaca dan mengetahui perasaan orang lain melalui bahasa tubuh verbal dan non-verbal seperti ekspresi wajah, gerak-gerik, dan nada bicara.

\section{Faktor Empati}

Beberapa faktor yang mempengaruhi tingkat empati seseorang (Hoffman, 2000) adalah:

a. Sosialisasi

Melalui sosialisasi dan pelatihan, seseorang akan mampu mengalami beberapa macam emosi untuk dapat berpikir dan memperhatikan orang lain sehingga menimbulkan respon pro-sosial dan mengembangkan rasa empati

b. Mood dan feeling

Seseorang lebih dapat berinteraksi dan menghadapi orang lain dengan baik jika memiliki perasaan yang baik

c. Proses belajar dan identifikasi 
Dari isi, seseorang akan memiliki respon yang berbeda-beda dari berbagai situasi sehingga dapat memaksimalkan proses belajar

d. Situasi dan tempat

Ada beberapa situasi yang dapat membuat orang dapat lebih berempati dengan baik, hal ini karena situasi dan tempat memberikan suasana yang beragam

e. Komunikasi dan bahasa

Komunikasi dan bahasa yang baik akan lebih mudah ditangkap seseorang sehingga empati lebih dapat terasa dan tidak salah dimengerti

f. Pengasuhan

Faktor lingkungan keluarga sangat mempengaruhi pola pengasuhan empati di dalamnya. Pengasuhan dalam keadaan keluarga yang baik akan menumbuhkan empati yang baik.

\section{Manfaat Positif Empati}

Beberapa manfaat empati (Daniel Goleman, 1997, hal. 89):

a. Sadar bahwa setiap manusia memiliki sudut pandang yang berbeda, sehingga dapat menyesuaikan diri dengan sekitarnya

b. Mampu mendorong untuk mengurangi penderitaan orang lain serta rasa tidak nyaman melihat penderitaan orang lain, sehingga menghambat perilaku yang tidak baik pada orang tersebut

c. Mampu memahami sudut pandang orang lain, sehingga dapat menilai seseorang berdasarkan perilaku.

\section{An Architecture of Seven Sense}

Arsitektur tidak hanya sebuah ilmu dalam menciptakan tempat tinggal, tetapi memiliki tujuan dalam segi metaphysical dan mental karena bangunan secara khusus dapat berbicara pada tubuh dan perasaan manusia (Juhani Pallasmaa, 1994). Arsitektur tidak hanya diciptakan dan dinikmati lewat mata saja, hal ini disebut sebagai "ocularenctic" (diadaptasi dari profesor Martin Jay) atau "retinal architecture". Menurutnya, arsitektur sekarang tidak menyentuh pada esensi sensual, seperti pada penggunaan material yang tidak dapat menyampaikan apapun dari mana asalnya maupun ketahanan material tersebut seperti pada kaca dan elemen sintetis yang sangat berbeda dibandingkan kayu, batu, maupun bata. Hal tersebut yang mengakibatkan arsitektur sekarang terasa hampa, dingin, tak bernyawa, keras, steril, berjarak dengan manusia, kehilangan sensualitas, bahkan tidak manusiawi, sehingga berbanding terbalik dengan idealitas yang dianutnya yaitu arsitektur seharusnya bergerak mengikuti waktu.

Di sini, Pallasmaa menyatakan bahwa pengalaman multisensoris harus dimiliki dalam sebuah bangunan karena interaksi esensial antara pengguna dan arsitektur dapat mengaktifkan semua indera dan memperkuatnya. Sehingga hasil pengalaman ini dapat memberikan informasi kognitif pada otak, serta mempengaruhi jiwa dan perasaan pengguna (afektif) yang disebut sebagai life enhancing ecperience atau pengalaman yang memperkuat jiwa (Susan Janehall, 2008). Visual dapat diwujudkan melalui cahaya dan bayangan, sentuhan melalui berat, kepadatan suhu dan material, kekuatan otot dan rangka melalui skala ruang, serta lidah melalui visual. Sedangkan aroma memberikan pengaruh memori yang paling kuat.

Life enhancing experience ini adalah pengalaman ruang yang melibatkan berbagai sensorisensori dan kesadaran terhadap lingkungan yang terdiri dari materialitas, sentuhan, tekstur, berat, kepadatan ruang, dan perwujudan cahaya dari lingkungan tersebut. Menurut Johann Wolfgang von Goethe, seni dapat meningkatkan hidup manusia melalui pengalaman dan sensasi kehangatan, kenyamanan, bermain, keingintahuan serta ketenangan. la menjelaskan 
bahwa ketujuh indera terdiri dari visual dari mata, suara dari telinga, aroma dari hidung, tekstur dari kulit, rasa dari lidah serta pergerakan dari otot dan rangka.

\section{The Eyes of The Skin: Architecture and Senses}

Indera peraba harus diperkuat dalam arsitektur di mana harus terhubung pada faktor pada bawah sadar manusia (Pallasmaa, 2005). Bangunan juga harus mampu menstimulus indera peraba dari pada visual manusia agar dapat merasakan sesuatu yang lebih intens tanpa melihat dan dengan mata tertutup. Terdapat beberapa faktor kunci yang memunculkan kepekaan indera melalui bangunan yaitu melalui pencahayaan, warna, materialitas, dan detail yang haptic menggunakan indera peraba. Pallasmaa sangat mendukung "international roughness" di mana hal ini merupakan bentuk penghindaran dari kesempurnaan permukaan yang dapat menimbulkan perasaan keterbukaan dan kesan yang mengundang.

\section{Fenomenologi}

Pengalaman arsitektur pada tubuh manusia ini cukup erat kaitannya dengan fenomenologi yang terinspirasi dari filosofi Merleau-Ponty yaitu bahwa tubuh adalah pusat kehidupan manusia.

\section{Emosional dalam Arsitektur}

Pada konferensi Anfa 2016 emosi pada otak manusia terus menerus menyesuaikan dengan lingkungan sekitar. Berfokus pada lingkungan yang sehat dapat mempengaruhi kesehatan, dan pengobatan serta mengembalikan ingatan lama melalui rangsangan otak. Hal ini dapat mempengaruhi perilaku seseorang melalui sensasi dan persepsi bagaimana otak mempengaruhi pengambilan keputusan bahkan emosi. Beberapa cara di antaranya yaitu melalui bagaimana mendengar, merasakan, dan bahkan mencium sesuatu yang berpengaruh pada penyimpanan informasi yang diterima dan mengingat informasi tersebut seperti salah satunya ketakutan. Semua hal itu dipengaruhi oleh desain lingkungan, sehingga arsitektur memiliki peran yang sangat penting dalam pengalaman yang dirasakan. Dalam penerapannya, arsitektur dapat menggunakan berbagai elemen yang dapat memicu emosi tertentu, beberapa di antaranya seperti air, ketinggian plafon, cahaya alami, warna, dan gaya. Elemen-elemen ini dapat merangsang emosi ketertarikan, kesenangan, minat, relaksasi bahkan stres.

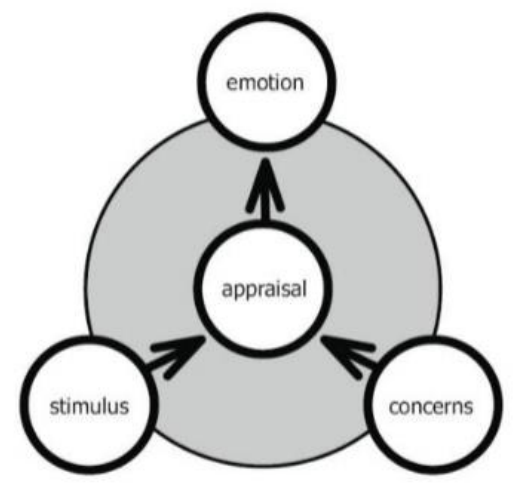

Gambar 1. Diagram dasar terbentuknya emosi Sumber : Simon Droog, (2009:12)

\section{METODE}

Data diperoleh melalui Badan Pusat Statistik DKI Jakarta dan Jakarta Barat, jurnal - jurnal ilmiah, e-book, dan wawancara serta kuisioner singkat dengan beberapa penduduk daerah kawasan Pegadungan Jakarta Barat yang tinggal menetap pada area tersebut, satpam penjaga (25 - 55 tahun) serta survei kawasan studi yang terpilih. 
Dalam proses perancangan ini, terdapat beberapa metode penelitian dan perancangan yang digunakan:

a. Pendekatan komunikasi merupakan pendekatan yang digunakan melalui komunikasi dengan melakukan wawancara secara individu maupun secara berkelompok

b. Observasi, pendekatan dengan cara menyaksikan, memperhatikan dan mengamati kejadian yang terjadi pada lokasi berdasarkan kebiasaan dan perilaku masyarakat

c. Korelasi, merupakan salah satu teknik analisis dalam statistik yang digunakan untuk mencari hubungan antara dua variabel yang bersifat kuantitatif

d. Fenomenologi menurut teori Juhani Pallasmaa An Architecture of Seven Sense dan The Eyes of The Skin: Architecture and Senses tentang penghidupan penginderaan manusia dalam desain arsitektur

e. Metode desain menggunakan karakteristik empati menurut Daniel Goleman.

\section{DISKUSI DAN HASIL}

\section{Analisis Lokasi}

Tapak yang diambil berada di kelurahan Pegadungan, kecamatan Kalideres, Jakarta Barat yang merupakan salah satu kawasan perumahan menengah ke atas terbesar di Jakarta Barat yang terdiri atas 8 perumahan dan 2 perkampungan. Tapak teripilih berdasarkan kelurahan yang terdiri dari berbagai perumahan dan perkampungan yang memiliki tingkat individualisme tinggi dengan melihat kehidupan bertetangga di kota besar.

Kriteria pemilihan tapak yaitu:

a. Berada di sekitar perumahan

b. Mudah diakses dengan menggunakan kendaraan umum maupun pejalan kaki

c. Berada di tempat yang agak jauh dari keramaian.

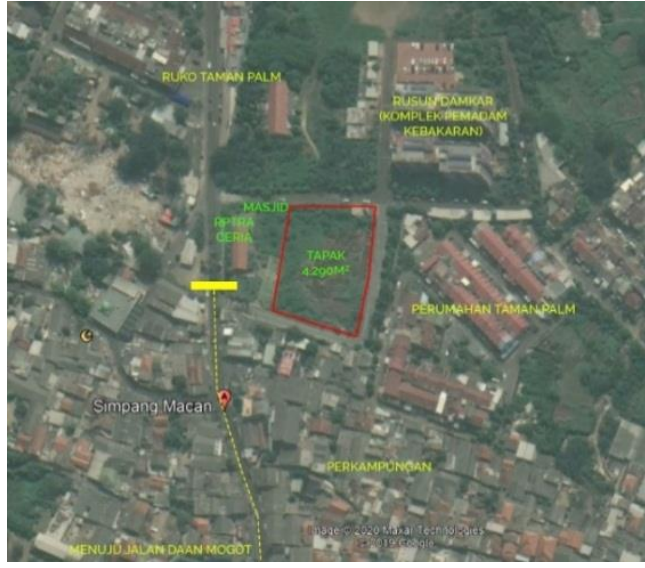

Gambar 2. Zoning Tapak

Sumber : Penulis, Google maps, 2020

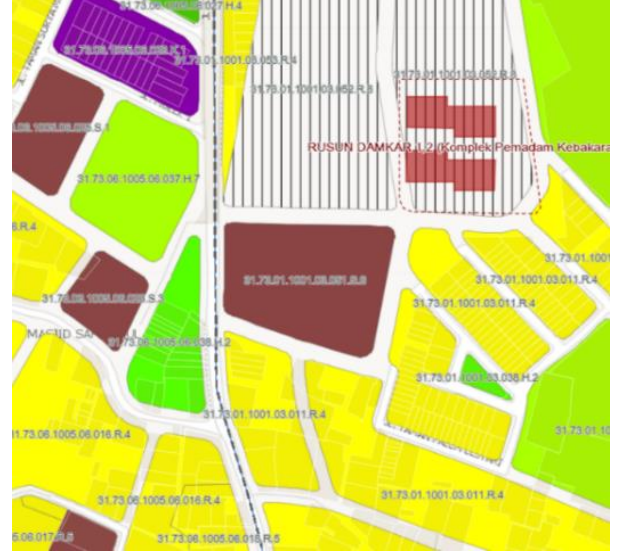

Gambar 3. Peta Zonasi

Sumber : Jakartasatu, 2020

Lokasi tapak: Jl. Taman Surya Bulevar, Pegadungan, Jakarta Barat

Luas tapak: $4.330 \mathrm{~m}^{2}$

Zona: Zona Pelayanan Umum dan Sosial

KDB: 40

KLB: 1.6

$\mathrm{KB}: 4$

$\mathrm{KDH}: 35$

KTB: 50

Luas total bangunan: $4.244 \mathrm{~m}^{2}$ 


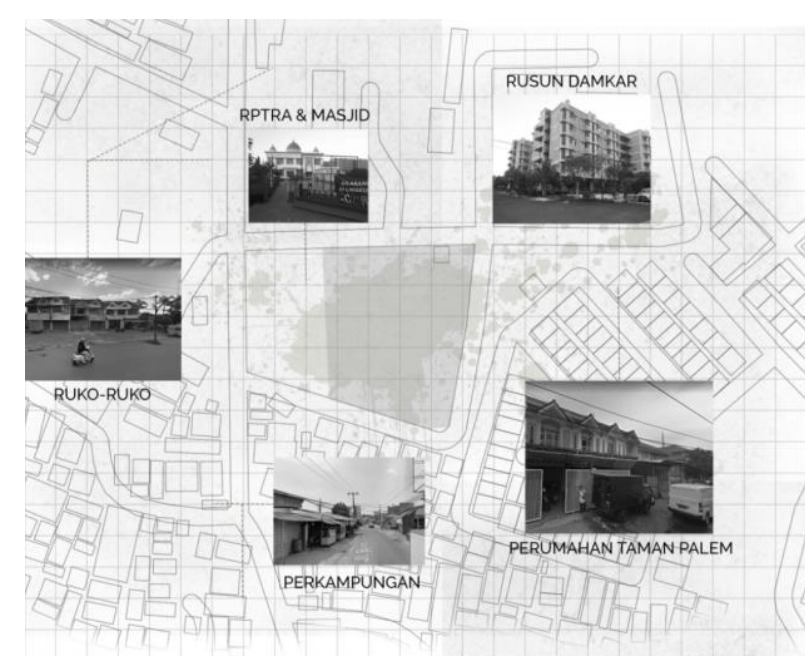

Gambar 4. Bangunan Sekitar Tapak

Sumber : Penulis, 2020

Dilihat dari data zonasi yang merupakan zona pelayanan umum, tapak ini sangat cocok untuk fungsi bangunan yang akan diterapkan yaitu performance dan rekreasi melihat daerah ini terdiri dari perumahan yang membutuhkan tempat hiburan bersama, juga dilintasi banyak orang saat berangkat maupun pulang bekerja. Tapak ini memiliki beberapa bangunan di sekitarnya antara lain RPTRA Ceria, masjid, ruko dan toko, Rusun Damkar serta perumahan Taman Palm Lestari yang dapat dimanfaatkan sebagai penghubung untuk menciptakan sebuah rembesan dan menggabungkan berbagai fungsi.

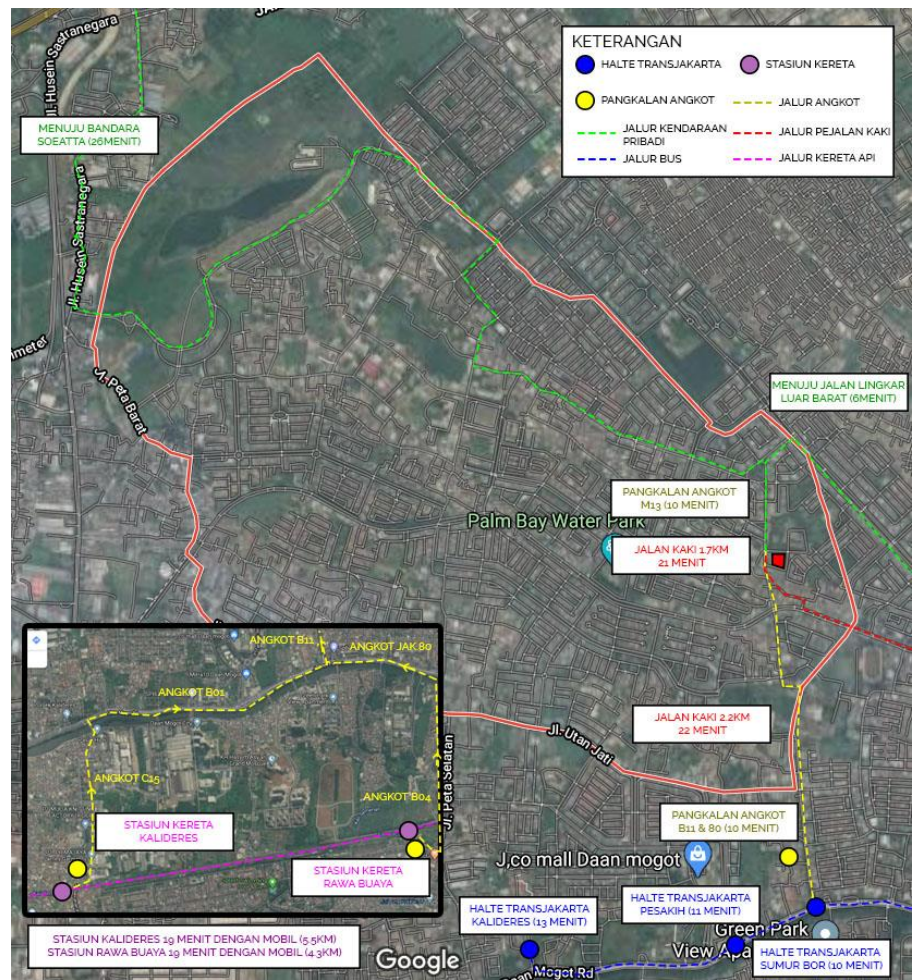

Gambar 5. Mapping Aksesibilitas di Pegadungan

Sumber : Penulis, Google maps, 2020

Daerah kelurahan Pegadungan memiliki beberapa moda transportasi yang melewatinya di antaranya seperti bus Transjakarta dan KRL yang keduanya berada di sepanjang jalan Daan Mogot. Selain itu, moda transportasi di dalam kelurahan meliputi bus Kopaja dan Metromini. 
Sebagian besar jalan yang dapat diakses oleh pejalan kaki dengan menggunakan kendaraan umum terdapat pada jalan Utan Jati yang mengarah ke jalan Daan Mogot. Sedangkan akses menuju tol Lingkar Luar Barat dan Bandara Soekarno Hatta harus menggunakan kendaraan pribadi karena melewati daerah perumahan sehingga tidak dapat diakses secara umum. Sehingga tapak yang diambil berada di sekitar jalan Utan Jati sehingga lebih mudah diakses pejalan kaki.

\section{Konsep Bangunan}

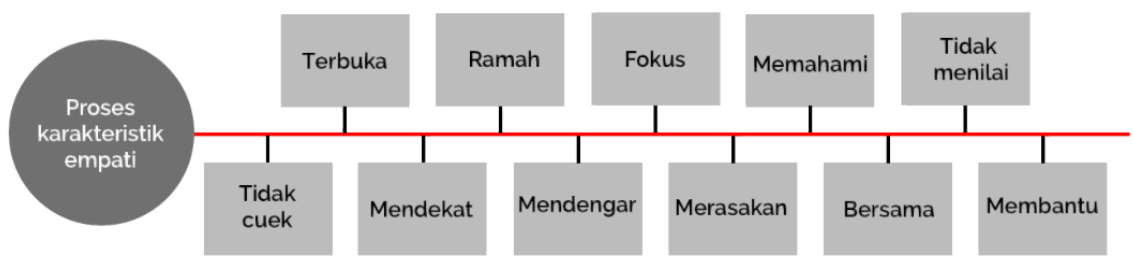

Gambar 6. Diagram Konsep Proses Karakteristik Empati

Sumber : Penulis, 2020

Konsep bentuk bangunan didapat berdasarkan beberapa karakteristik empati yang didapat melalui dasar ciri-ciri kemampuan empati menurut (Daniel Goleman, 1996). Beberapa karakteristik yang terdapat pada labirin dapat disimpulkan sebagai berikut:

a. Terbuka: bangunan terbuka untuk semua orang melalui akses masuk dari berbagai macam arah pada labirin, bentuk, dan pola ruang

b. Mendekat: pergerakan pengguna yang mendekat ke tengah pada labirin kemudian menyebar ke program yang tersedia. Hal ini dapat dilihat dari bentuk labirin yang memiliki 1 tujuan dari 5 jalan masuk.

c. Fokus: bangunan terfokus pada titik tengah yaitu panggung sebagai pusat kegiatan

d. Merasakan: program yang membuat semua orang dapat merasakan perasaan yang sama melalui labirin dengan melatih emosi masing-masing individu

e. Memahami: memahami kebutuhan masyarakat sekitar melalui program yang tersedia

f. Bersama: kegiatan yang menimbulkan kebersamaan (workshop, panggung, dan tempat piknik)

g. Tidak menilai: bangunan bersifat netral dan menimbulkan pertanyaan (labirin)

h. Membantu: membantu meningkatkan empati melalui permainan emosi dan program yang ada.

\section{Analisis Program Kegiatan}

Proyek ini diharapkan dapat meningkatkan empati masyarakat melalui pendekatan fenomenologi arsitektur dalam pengendalian emosi seseorang dengan usulan program yang mengacu pada kebutuhan dan hobi dari masyarakat sekitar melalui pengamatan, survei, dan kuisioner. Konsep yang digunakan mengacu pada pengalaman ruang yang akan tercipta pada flow bangunan. Menurut wawancara dengan masyarakat sekitar, masyarakat memiliki hobi menonton bersama, terutama oleh ibu-ibu dan anak-anak, dan menanam tanaman hias di sekitar rumahnya menurut pengamatan. Setiap ruang dari flow yang tersedia memiliki makna dan menimbulkan emosi yang berbeda-beda pula.

\section{Labirin}

Merupakan sebuah tempat yang memiliki jalur yang rumit, berliku, dan memiliki banyak jalan buntu, di mana orang akan dibuat bingung untuk mencari jalan keluar. Penggunaan labirin agar masyarakat dapat merasakan dan memahami perasaan depresi, kesusahan, kesedihan, dan 
bingung bersama-sama, karena seseorang akan dapat berempati bila pernah merasakan masalah yang dialami orang lain. Labirin berbentuk terpusat dan mengecil serta memiliki cabang dan jalan buntu yang mempersulit orang untuk keluar. Pada labirin inilah akan tercipta rasa empati secara tidak langsung dengan bantuan-bantuan orang di atas maupun orang-orang yang terjebak di labirin. Mereka akan merasakan depresi dan kebingungan bersama, lalu akan mencari jalan keluar bersama. Labirin berupa cermin yang membingungkan tetapi memiliki petunjuk tersembunyi untuk dapat keluar, selain itu lubang ventilasi dapat digunakan sebagai wadah orang di atas untuk memberi instruksi.

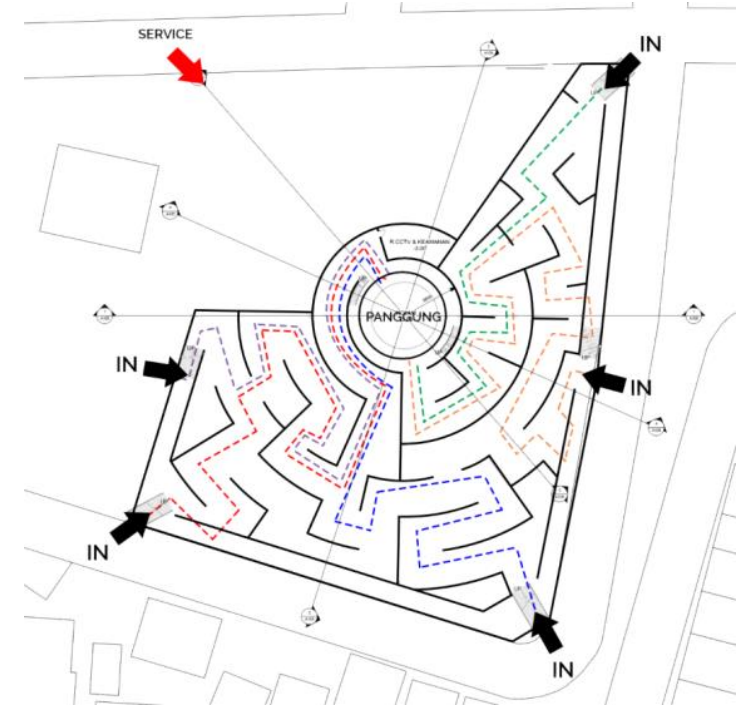

Gambar 7. Rute Labirin

Sumber: Penulis, 2020

\section{Panggung Performance}

Merupakan sebuah wadah pengalir empati, di mana kegiatan yang menyenangkan dan menghibur dapat disalurkan melalui program ini, seperti menyanyi, menari, seni peran atau drama, bercerita, menonton film bersama, dan seminar-seminar. Kegiatan di sini menciptakan rasa bahagia bersama-sama dengan orang-orang yang menonton setelah melewati labirin. Di tempat inilah orang dapat bersenang-senang bersama setelah melewati kesusahan.

\section{Tempat Piknik}

Tempat di mana masyarakat dapat berkumpul bersama untuk menonton performance. Masyarakat daerah Pegadungan ini memiliki hobi menonton bersama terutama ibu rumah tangga dan anak-anak, mereka membutuhkan sebuah tempat berkumpul sambil mengisi waktu luang. Kebersamaan dan rasa bahagia ini yang dapat menciptakan empati.

\section{Galeri dan Mural}

Masyarakat sekitar yang memiliki hobi dalam melukis, fotografi, memahat, dan kerajinan dapat menuangkan hobi dan bakatnya di sini. Hasli karya maupun cerita mereka mengenai empati maupun pengalaman di proyek ini dapat dipajang dan menjadi contoh bagi masyarakat yang ingin belajar berempati lebih dalam. Mural pada ruang transisi saat keluar dari labirin dapat berupa gambar dengan pesan-pesan mengenai empati dan kesan mereka saat memasuki bangunan ini. 


\section{Workshop}

Kegiatan workshop yang dilakukan di sini adalah menanam tanaman hias di sekitar tapak dan merangkai bunga tersebut bersama-sama. Melihat kesamaan dari beberapa masyarakat yaitu memiliki tanaman hias di rumahnya, kegiatan ini dapat menjadi pemersatu hobi mereka. Memiliki tanggung jawab dan kepentingan yang sama, menjadikan mereka lebih dapat berbaur. Empati dimunculkan melalui kegiatan merangkai bunga bersama dan saling bertukar satu sama lain dengan menerapkan sharing is caring.

\section{Ruang Pelatihan Empati}

Terdapat pula ruang pelatihan empati berupa sebuah kelas yang ditunjukkan untuk masyarakat yang ingin mempelajari dan mendalami empati melalui pembelajaran. Pelatihan ini mempelajari secara langsung, dengan mengamati kegiatan bangunan dan mempraktekannya kepada masyarakat. Sehingga, dapat dipahami secara lebih mendalam dan tujuan empati dapat tersampaikan dengan jelas.

\section{Kafetaria}

Sebuah tempat tambahan sebagai sarana komersial dengan harga terjangkau bagi seluruh kalangan masyarakat. Selain itu, keberadaan kafetaria ini diperlukan untuk menunjang pembiayaan manajemen karena tempat ini dibuka untuk umum secara gratis.

\section{Taman Bunga}

Tempat ini berupa sebuah landscape di sekitar bangunan yang terdiri dari berbagai macam bunga. Selain sebagai wadah menyalurkan hobi masyarakat dalam menanam tanaman hias, taman bunga ini memberikan kesan alam yang rileks, menyenangkan serta sehat. Berbagai wewangian bunga pun dapat menimbulkan kebahagiaan dan semangat seperti pada bunga Geranium, Lavender, Mawar, Melati, Tulip, dan Lili.

Tabel 1. Persentase Program Ruang

\begin{tabular}{|c|c|c|c|c|c|}
\hline Labirin & Open space & Ruang transisi & Kegiatan \\
utama & $30 \%$ & $10 \%$ & $30 \%$ & $10 \%$ & Kafetaria \\
& & & & & \\
& & & & & \\
\hline
\end{tabular}

Sumber: Penulis, 2020

\section{Proses Gubahan Massa Pada Labirin}

1.

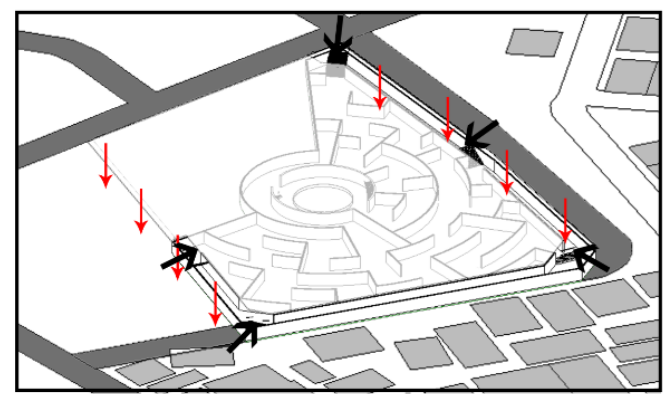

Gambar 8. Akses Masuk Bangunan ke Dalam Tanah Sumber : Penulis, 2020

Bentuk sesuai arah masuk tapak ke dalam tanah sebanyak 5 arah membentuk siku. Akses masuk ini menjawab karakteristik terbuka dan mendekat. Arah masuk utama menghadap ke jalan lingkungan rusun Damkar. 
2.

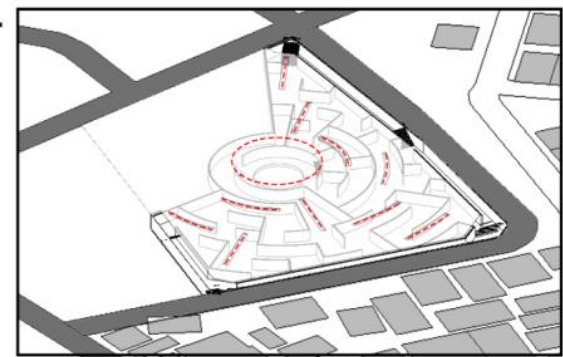

Gambar 9. Pembentukan Ventilasi Pada Labirin Sumber : Penulis, 2020

Ventilasi dan pecahayaan labirin terbentuk sesuai dengan petunjuk keluar labirin dan wadah interaksi dengan orang di atas untuk membantu yang membentuk pola di atas tanah.

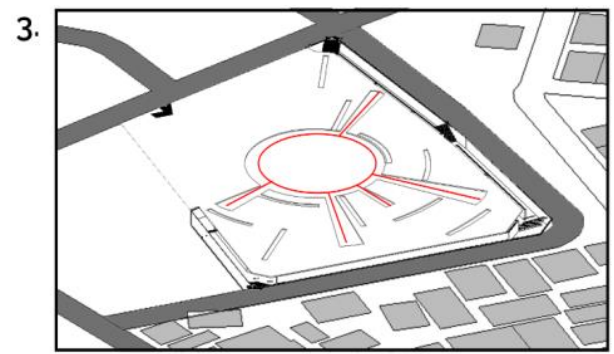

Gambar 10. Bentuk Memusat dan Menyebar Pada Bangunan Sumber : Penulis, 2020

Bangunan bersifat memusat dan bercabang ke segala arah untuk menjawab karakteristik mendekat dan fokus.

\section{Pengalaman Emosi}

Konsep ini berupa flow ruang yang menimbulkan berbagai macam emosi dari orang datang sampai pulang dengan pendekatan fenomenologi. Hal ini bertujuan agar masyarakat dapat berempati dari proses awal terjadinya sampai berhasil merasakan empati bersama-sama. Beberapa proses emosi yang dirasakan adalah emosi normal, di mana orang datang dengan perasaan normal kemudian mengalami depresi, seseorang akan dapat berempati jika sudah pernah merasakan kesulitan dan masalah. Setelah itu sikap saling membantu akan terwujud setelah merasakan depresi dan menyelesaikannya, yang kemudian dapat bersenang-senang bersama.

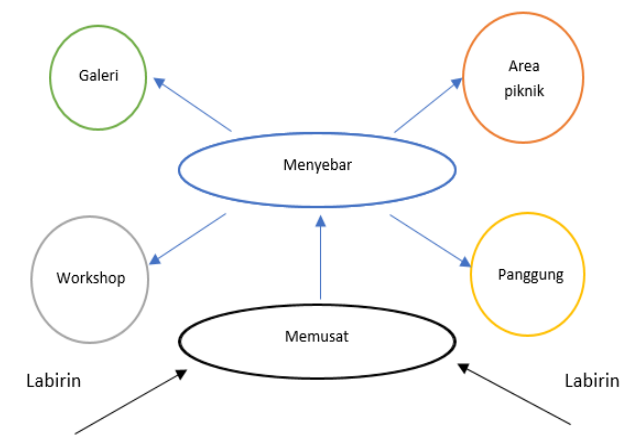

Gambar 11. Diagram flow ruang Sumber : Penulis, 2020 


\section{Material Bangunan}

Konsep diwujudkan pula melalui material bangunan untuk mendukung pengalaman emosi yang tercipta. Material merupakan salah satu perwujudan dari indera peraba melalui tekstur dan suhu pada teori Juhani Pallasmaa yaitu "The Eyes of The Skin: Architecture and Sense (2005)". Pada labirin, material yang digunakan adalah cermin yang digunakan sebagai dinding untuk memberi kesan refleksi dan kebingungan pada pengguna, dan beton eskspos digunakan pada lantai dan plafon untuk memberi kesan dingin dan kasar.

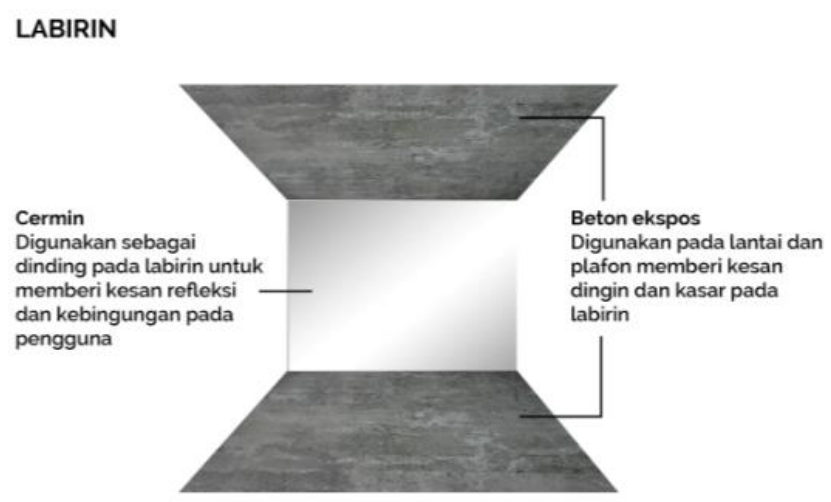

Gambar 12. Material yang digunakan pada labirin Sumber : Penulis, 2020

\section{Warna dan Bentuk}

Warna dan bentuk merupakan sebuah perwujudan dari indera penglihatan, serta otot dan rangka melalui visual dan bentuk ruang dengan menggunakan teori dari Juhani Pallasmaa yaitu "An Architecture of Seven Sense (1994)". Selain itu cahaya alami yang masuk dapat mempengaruhi emosi pula. Seperti pada labirin yang hanya memiliki sumber cahaya alami yang sedikit tidak banyak menimbulkan perasaan bahagia. Sebaliknya pada bangunan memiliki banyak sumber cahaya alami dengan bangunan yang terbuka dapat menimbulkan perasaan bahagia dan ramah lingkungan. Pada labirin menggunakan warna-warna yang menimbulkan perasaan tidak nyaman seperti abu-abu yang berkesan dingin dan hampa, hitam menandakan kemisteriusan, dan merah yang digunakan pada cahaya yang menandakan bahaya. Labirin berbentuk terpusat dan mengecil, serta bercabang dan memiliki banyak jalan buntu. Labirin yang digunakan berbentuk radial dengan jalan keluar di tengahnya yang merupakan pusat bangunan, untuk menjawab karakteristik dari empati yaitu mendekat dan fokus. 
LABIRIN

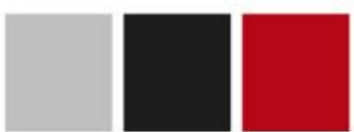

Menggunakan warna-warna yang menimbulkan perasaan tidak nyaman 1. Abu-abu berkesan dingin dan hampa 2. Hitam: menandakan kemisteriusan 3. Merah digunakan pada cahaya yan menandakan bahaya
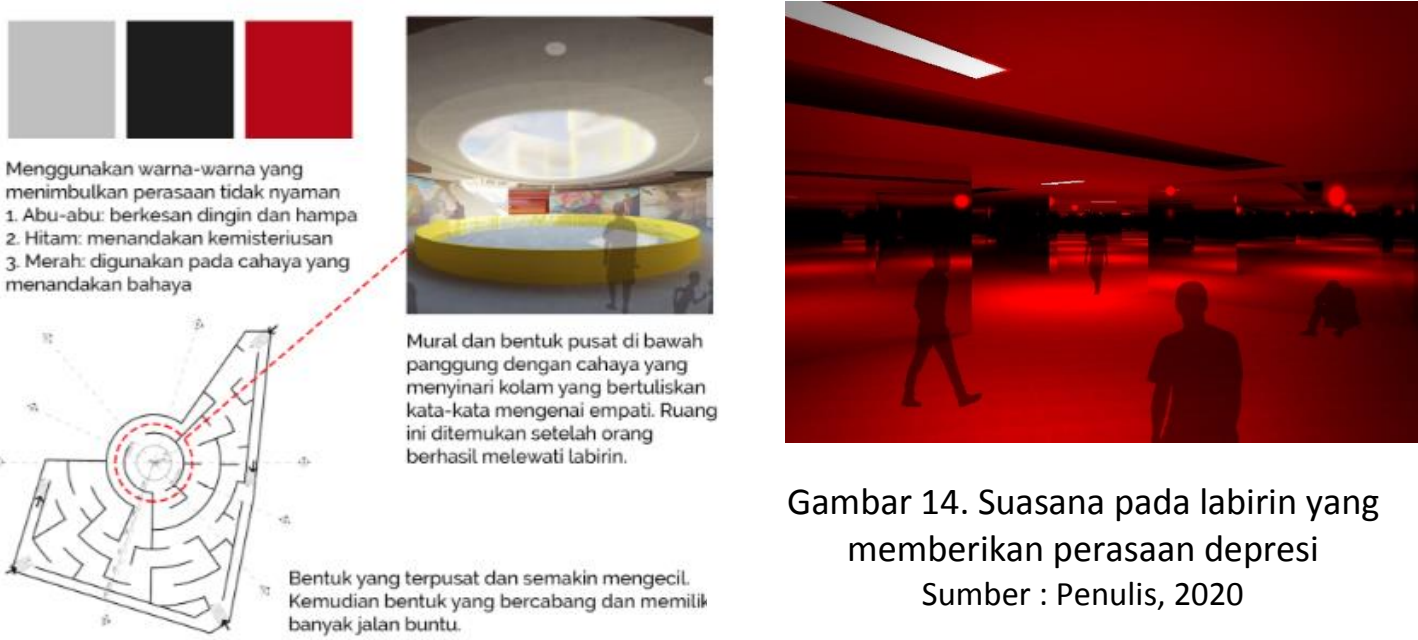

Gambar 14. Suasana pada labirin yang memberikan perasaan depresi Sumber : Penulis, 2020

Gambar 13. Penggunaan warna dan bentuk pada labirin

Sumber : Penulis, 2020

\section{Komponen Lain Pada Labirin}

a. Penglihatan:

- Bentuk: dari luas ke sempit memberikan kesan tertekan. Bersudut dan buntu memberikan kesan ketakutan dan kebingungan. Bangunan berbentuk organik yang mengacak tetapi teratur memberikan kesan bingung.

- Warna: menggunakan warna hitam memberikan rasa kemisteriusan, ketakutan dan rasa tidak bahagia. Merah menunjukkan bahaya (dapat digunakan untuk pencahayaan). Abuabu memberikan kesan dingin dan hampa.

- Cahaya: menggunakan sedikit cahaya alami.

- Refkeksi: menggunakan cermin yang membuat orang menjadi bingung.

b. Penciuman

- Aroma: bau lembab menimbulkan kesan terbengkalai, tidak terawat, tertutup.

c. Pendengaran

- Suara: Hening seperti tuli memberikan kesan kepanikan, khawatir dan cemas. Selain itu, kegaduhan dapat menimbulkan perasaan stress dan memicu perilaku agresif yaitu pada 35-45db.

d. Perasaan

- Tekstur: menggunakan tekstur yang kasar untuk memberikan kesan berat dengan menggunakan material beton.

- Suhu: suhu yang panas dapat mempengaruhi intensitas atensi seseorang menjadi lebih rendah.

- Kelembaban: lembab menimbulkan kesan terbengkalai, tidak terawat, dan tertutup.

\section{KESIMPULAN DAN SARAN}

\section{Kesimpulan}

Masalah penurunan tingkat empati di daerah kota besar seperti Jakarta tidak dapat diabaikan, karena ini merupakan hal penting seperti yang dinyatakan oleh Graaff, dkk (2014) di mana empatilah yang menggaris bawahi pentingnya kemampuan, tingkah laku dan sebuah peran yang sangat penting dalam pengembangan moral dan perilaku prososial. Jika dibiarkan, 
masyarakat akan menjadi individualis dan tidak peduli terhadap lingkungan yang dapat berdampak bagi kebutuhan sosial manusia. Sehingga pada proyek Wadah Pengembangan Empati Pegadungan, diterapkanlah sebuah pengalaman ruang dan program melalui pendekatan fenomenologi dan berdasar kepada karakteristik empati sendiri, salah satunya melalui labirin. Di sini arsitektur berperan dalam meningkatkan dan mempertahankan empati melalui ruang-ruang yang tercipta.

\section{Saran}

Arsitektur juga dapat berperan dalam mengubah tingkah laku manusia melalui aspek psikologi. Hal ini dapat dilakukan melalui pendalaman psikologi ruang pada ruang yang mampu mengatur emosi seseorang. Arsitektur diharapkan dapat berbicara pada tubuh dan perasaan manusia dengan menyentuh pada esensi sensual melalui material. Hal ini disampaikan oleh Juhani Pallasmaa sehingga arsitektur dapat menjadi lebih manusiawi. Penelitian dan studi ini masih memerlukan penyempurnaan mengingat kurangnya referensi dan teori yang pasti tentang peningkatan empati.

\section{REFERENSI}

Aoun, R. G. (2016). Emotional Design in Architecture. Retrieved June 24, 2020, from https://www.brikbase.org/sites/default/files/2016-09-

16\%20ANFA\%20Conference\%20Abstract_03.pdf

Baron \& Byrne. (2004). Psikologi sosial jilid 2. Jakarta: Erlangga. Droog, S dan Paul de V. (2009). Emotion in architecture: The experience of the user. Goleman, D. (1996). Kecerdasan emosional. Jakarta: PT. Gramedia Pustaka Utama. Goleman, D. (2007). Kecerdasan emosi untuk mencapai puncak prestasi. Jakarta: PT. Gramedia Pustaka Utama.

Hodiono, R. (2016). Hubungan Antara Pola Asuh Otoriter Orang Tua Dengan Empati Pada Remaja Awal. Skripsi thesis, Universitas Mercu Buana Yogyakarta.

Hoffman, M. L. (2000). Empathy and moral development: Implications of caring and justice. New York: Cambridge University Press.

https://issuu.com/pauldevries/docs/20090202_emotioninarchitecture_big

Janehall, S. (2008). Enchanting well-being: A multisensory interior environmental experience: An application of Juhani Pallasmaa's theory of architecture to interior space. Thesis. Washington D.C.: Washington University.

Pallasmaa, J. (2005). The eyes of the skin : Architecture and sense. Cornwall, Great Britain : TJ International

Ltd.

Padstow.

Pallasmaa, J., Holl, S., Perez-Gomez, A.. (1994). An architecture of seven sense: Architecture and urbanism question of perception. Tokyo: A+u Publishing.

Rossa, V. (2020). Studi: 65 Persen Orang Kehilangan Rasa Empati. Diakses 24 Juni 2020, dari https://www.suara.com/lifestyle/2019/04/23/161121/studi-65-persen-orang-kehilanganrasa-empati.

Sabatini, S. N. (2017). Sumbangsih Juhani Pallasmaa dalam Teori Arsitektur. Jurnal RUAS, 15(2). ISSN 1693-3702.

Van der Graaff, J., Branje, S., De Wied, M., Hawk, S., Van Lier, P., \& Meeus, W. (2014). Perspective Taking and Empathic Concern in Adolescence: Gender Differences in Developmental Changes. Developmental Psychology,50(3) 